\title{
Influence of Product Types on Consumer's Attitude towards Online Shopping: An Empirical Study in the Indian Context
}

\author{
Hemamalini K. ${ }^{1}$ \\ ${ }^{1}$ Department of Management Studies, Dr.SNS Rajalakshmi College of Arts and Science, India \\ Correspondence: Hemamalini K, Department of Management Studies, Dr.SNS Rajalakshmi College of Arts and \\ Science, Coimbatore 641029, India. E-mail: hema8448@gmail.com
}

Received: June 10, 2013

doi:10.5539/ijms.v5n5p41

\author{
Accepted: July 5, 2013 \\ Online Published: August 6, 2013 \\ URL: http://dx.doi.org/10.5539/ijms.v5n5p41
}

\begin{abstract}
The study empirically examined the product types of online shopping within a proposed model with respect to factors like personal internet awareness, product involvement, attitude and reason to shop online. Although prior research projects have examined the factors that impact the adoption of technology or Internet, there is limited empirical work in the Indian context which simultaneously captures the information on online shopping for different product types. The study found that product involvement, attitude and reason for online shopping varied with different product types.
\end{abstract}

Keywords: online shopping, internet shopping, internet awareness, product types, product involvement, reason to shop online, attitude towards online shopping

\section{Introduction}

The Internet has paved the way for the emergence and growth of electronic business (e-business). E-business is defined as the process of using electronic technology to perform business. One of the models of e-business matrix is Business to Consumer (B2C), which refers to online shopping (Internet shopping) for consumers. Online shopping in India has grown 128 percent in 2012-2013 compared to only 40 percent the previous year 2011-2012 according to Google Online Shopping Growth in India - 2013. Indians like the idea of shopping through the Internet as reported by Google India trends. From the reports of Google India trends in 2012, it has been stated that 2013 be a strong growth year for categories like apparels, accessories, baby products, home furnishings, and health nutrition. And this growth is expected to come from outside of the top eight metro cities in India (Google Online Shopping Growth in India - 2013).

A few years ago, consumers purchased clothes from malls, books from bookstores, traded stock through brokers. With the emergence of Internet and Online shopping, businesses are coming to our doorstep. A number of companies have successfully established an electronic outlet through online portals. Although previous research projects have examined the factors that impact the adoption of technology or Internet, there is limited empirical work in the Indian context which simultaneously captures information on online shopping for different product types.

\subsection{Importance of the Study}

Previous studies examined variables like personality traits, self efficacy, demographic profiles, technology awareness, perceived ease of use and acceptance of new Information Technology (IT) applications. In order to investigate consumer's attitude towards online shopping, we need to understand consumer characteristics. Attitude toward online shopping is defined as positive or negative feelings related to online shopping. In the Indian context there are very few researches on Online shopping with respect to product types.

The development of internet has facilitated online shopping. However, the participation in online shopping depends on different factors and product types marketed through internet.

Phau and Poon (2000) found that product type affects consumer decisions in selecting traditional or online shopping channels.

Liang and Huang (1998) expressed that in electronic markets, increased attention must be paid to understanding which products are suitable for marketing online. Particularly, they pointed that different product type's influence 
consumer online shopping acceptance.

Peterson, Balasubramanian, and Bronnenberg (1997) pointed that suitability for internet marketing depends on the characteristics of the products and services being marketed. Therefore, it is vital to consider the differences among product types to fully understand the influence of online shopping.

This is especially true in the context of consumers in Tier-II cities in India, where the consumers are less familiar with online shopping. Therefore the purpose of this study was to explore the influence of product types on consumer's attitude towards online shopping.

\subsection{Literature Review}

Zuroni and Goh (2012) studied the factors influencing online shopping. The main purpose of the study was to determine the factors influencing consumers' attitude towards e-commerce purchases. The findings revealed that there was no significant difference in attitude towards online shopping among age group (but there is a significant difference in attitude towards online shopping among income group. The study assessed the relationship between independent variable such as e-commerce experience, hours spent on internet, product perception, customers' service and consumers' risk and dependant variable such as attitude towards online shopping. The findings revealed that there was a significant relationship between e-commerce experience and attitude towards online shopping among the respondents. The study also indicated that there was a significant relationship between product perception and attitude towards online shopping among the respondents and there was also a significant relationship between customers' service and attitude towards online shopping among the respondents. The study also showed that there was no significant relationship between consumers' risk and attitude towards online shopping among the respondents.

Swaminathan, Lepkowska-White, \& Rao (1999) assessed whether customers are motivated by convenience or the social interaction associated with shopping. The respondents were asked whether they preferred dealing with people during shopping or affected by convenience of the shopping mode. The study shows that consumers who are motivated by convenience are more likely to purchase online. Those who value social interactions are less interested in the Internet use for shopping.

Jongeun Kim (2004) explored the attitudes of respondents towards purchasing products on the internet. The purpose of the research was to explore the differences between four potential groups of web users (the non-web user, the user who only visits web stores with no intention to buy, the internet browser who has an intention to purchase online but has never done so and the person who has made an online purchase). The study focused on understanding the differences among the four groups in terms of demographics, technology use and access and current attitude towards online purchase. The study concluded that the consumer factor showed a strong relationship in predicting online purchase intention and behavior while the marketing factor showed a moderate relationship. The study also reveled that the consumer attitude factor was a more significant predictor of internet purchasing than their demographic characteristics such as gender, ethnic profile and income.

Ramayah \& Joshua (2010) investigated online customer service, perceived ease of use and intention to shop online. Using Technology Acceptance Model (TAM) as a basis, the study observed customer service, perceived ease of use of the application on the intention to engage in e-shopping. The study revealed that perceived ease of use was a mediator between online customer service and intention to shop online. When online customer service and perceived ease of use was regressed together on intention to shop online, it was found that perceived ease of use significantly influenced intention to shop online $(\mathrm{p}<0.01)$.

Carol \& Jay (2002) indicated that shoppers who browse or purchase on the Internet had different perception of convenience. Some shoppers clearly want to purchase in the store setting and reject multiple forms of non-store shopping. Others like to browse various non-store media and have extended their browsing to the Internet, yet maintain their loyalty to in-store purchases.

Bill et al (2005) analyzed whether consumer's perceived risk of Internet shopping and experience were associated with online shopping behavior. The study measured perceived risk areas like inability to inspect product, inability to compare products, risk of credit card use, and risk of compromising on personal information. It was observed that perceived negative consequences of Internet shopping, specifically product and privacy risk and the loss of social interaction are closely associated with online purchasing behavior. Perceived risk seemed to obstruct Internet users from shopping frequently.

Sandra et al (2006) investigated the perceived benefits and risks of online shopping. The objective of the study was to investigate perceived benefits and risk, develop scales to validate with online shoppers. Two scales were developed to examine the role of perceived benefits and perceived risks, as well as the trade-offs that occur in 
consumers' decisions to shop online. The study stated that consumers select retail outlets that meet their expectations for dominant shopping motives and pursue value from the shopping experience, suggesting that consumer's trade-off perceived benefits and risks in forming an intention to purchase online. It was found that the risk concerns were diminishing with increased online shopping experience, while perceived benefits were becoming increasingly important.

Previous studies indicated that in terms of motivators to shop online, the consumers highlighted cash back guarantee, ability to give cash on delivery, fast delivery, great deals and access to branded products were highlighted amongst the benefits of shopping online (Google India 2013). The number one factor that discouraged consumers from shopping online was inability to feel the products before purchase, fear of damaged products, fear of sharing their personal and financial details online and the inability to bargain were cited among the other reasons (Google India 2013)

Rose Sebastianelli, Nabil Tamimi and Murli Rajan (2007) studied the US online consumer's perceptions regarding the quality of online shopping experiences. The research examined whether the frequency with which they purchase products online and the types of products they purchase affect their perceptions of internet retailer quality. In the study, the quality of online shopping is measured using a set of items that represent the four phases encountered when shopping via the Internet: (1) the retailer's homepage, (2) online product catalog (3) order form and (4) customer service and support. The study revealed that frequent online shoppers consider both reliability and product content significantly more important than infrequent online shoppers; ordering services is significantly more important to infrequent online shoppers. With regard to product type, they found some significant differences between online shoppers who purchase "search" versus "experience" products. Specifically, those who purchase experience products online rate ordering services and product content significantly more important than those who buy search products.

Girard (2003) examined whether the relationship of demographic variables, shopping orientation, purchased preference on the internet vary by the product type. The products employed in the study were classified into four categories; search (books, toys), two types of experience (Clothing, perfume, cell phone and televisions) and credence (vitamins and water purifiers) products. It was found that the relationship of shopping orientation and purchase preference significantly vary by product category. The convenience orientation positively influenced shopping online for experience- $1(t=4.26, p<0.01)$, experience- $2(t=1.99, p<0.05)$, and credence $(t=2.95, p$ $<0.01)$ product categories. The study indicated that convenience orientation was a stronger predictor for preference to shop on the Internet for the experience-1 products such as clothing and perfume. The recreational shopper orientation was a stronger predictor for preference to shop on the Internet for the experience- 2 products such as cell phones and televisions. In addition, convenience and recreational shopper orientations were equally strong predictors for preference to shop on the Internet for the credence products such as vitamins and water purifiers.

Lian and Lin (2008) studied four different products that included Books, Online magazines, TV gaming system and computer games. The research indicated that individual privacy concerns negatively influenced consumer attitudes toward buying books online. The analytical results indicated that individual privacy concerns negatively affected attitudes toward online purchases of TV gaming systems. For online news and magazines, only product involvement significantly and positively affected attitudes toward purchasing behavior. The perceived Web security and product involvement were found to positively affect attitudes toward online purchases of computer games.

\subsection{Product Classification}

Previous research has grouped products based on search, experience and credence ((Nelson, 1970, 1974). In the context of Internet, Peterson et al. (1997) proposed a more relevant classification system for classifying products for online.

The system designed by Peterson et al. (1997) is based on the following three dimensions:

Cost and purchase: from inexpensive, frequently purchased goods to expensive, infrequently purchased goods.

Value proposition: follows the product value proposition, and classifies the products as either tangible and physical products or intangible services.

Degree of differentiation: degree of product differentiation and enables the businesses to create competitive advantage. The three dimensions are illustrated in Table 1. 
Table 1. Product classification by Peterson et al. 1997

\begin{tabular}{|c|c|c|}
\hline Dimension 1 & Dimension 2 & Dimension 3 \\
\hline \multirow[t]{2}{*}{$\begin{array}{l}\text { Low cost, frequently } \\
\text { purchased goods }\end{array}$} & $\begin{array}{l}\text { Value proposition tangible or } \\
\text { physical }\end{array}$ & $\begin{array}{l}\text { Differentiation potential } \\
\text { high } \\
\text { Differentiation potential } \\
\text { low }\end{array}$ \\
\hline & $\begin{array}{l}\text { Value proposition intangible or } \\
\text { informational }\end{array}$ & $\begin{array}{l}\text { Differentiation potential } \\
\text { high }\end{array}$ \\
\hline \multirow[t]{2}{*}{$\begin{array}{l}\text { High outlay, infrequently } \\
\text { purchased goods }\end{array}$} & $\begin{array}{l}\text { Value proposition tangible or } \\
\text { physical }\end{array}$ & $\begin{array}{l}\text { Differentiation potential } \\
\text { high } \\
\text { Differentiation potential } \\
\text { low }\end{array}$ \\
\hline & $\begin{array}{l}\text { Value proposition intangible or } \\
\text { informational }\end{array}$ & $\begin{array}{l}\text { Differentiation potential } \\
\text { high } \\
\text { Differentiation potential } \\
\text { low }\end{array}$ \\
\hline
\end{tabular}

For the purpose of study, four products (Books, E-tickets, Insurance and Computers) have been considered based on Peterson et al. (1997) to evaluate consumer's attitude towards online shopping.

\subsection{Factors Considered for the Study}

Based on the above discussion, an integrated model including four factors and four products were proposed and tested for this study. The descriptions of the factors are listed below:

Personal Internet Awareness: Consumer attitude towards online shopping is affected by internet awareness as users with high level of awareness about technology and internet are more likely to use online shopping. This is considered based on the Personal innovativeness of information technology (PIIT) defined by Agarwal and Prasad (1998) as "the willingness of an individual to try out a new Information Technology".

Product Involvement: Product involvement reflects the relevance and interest of the consumer with a product. Zaichkowsky (1985) defined involvement as a person's perceived relevance of the object based on inherent needs, values, and interests. Product involvement has been measured by Likert statements that were thought to study the underlying concept-for example, the product means a lot to me, it matters to me, or the product is important to me. Lastovika (1979) analysed the homogeneity of consumer acquisition within a set of diverse product classes. The degree to which product involvement was related to levels of acquisition behavior was examined.The study revealed that across the seven products used in the research, consumers could generally be classified as more or less active in their acquisition behavior (Lastovicka, 1979).

Attitude towards online shopping: The attitude to shop online depends on the liking and interest of consumers. If customers like to buy online and find online shopping interesting they will increase buying online. Jarvenpaa et al. (2000) tested a model of consumer attitude towards specific web-based stores, in which perceptions of the store's reputation and size were assumed to affect consumer trust of the retailer. The level of trust was positively influenced the attitude toward the store, and negatively influenced the perception of the risks involved in buying from that store.

Perceived benefit or intention to shop online: The reason to shop online varies from consumer to consumer depending on the product they intend to shop online. Previous research examined perceived benefit in the context of intention to shop (Batra \& Ahtola, 1990). The research included functional intentions like variety, price and convenience. According to the Theory of Reasoned Action (TRA), a shopper's intention to buy is preceded by the shopper's attitudes toward the purchase (Jarvenpaa et al. 2000). Thus, a positive relationship is expected between attitudes towards online shopping of a product and reason to buy online.

\subsection{Research Model}

Based on the different factors in the literature review, product classification table proposed by Peterson et al. (1997) and Technology Acceptance Model (TAM) (Davis, 1989), an integrated model involving the key factors is tested in this study. TAM is widely used in understanding consumer behavior in technology usage. The TAM is designed for information system to study user's acceptance and usage of new technology. Although the model has been widely used as a theoretical framework in the recent studies to study technology acceptance, including the World Wide Web (WWW) and internet based system Park et al. (2001), there are not many research that 
includes product involvement. The current study employs TAM's belief-attitude-intention-behavior relationship in the context of the products selected for the study.

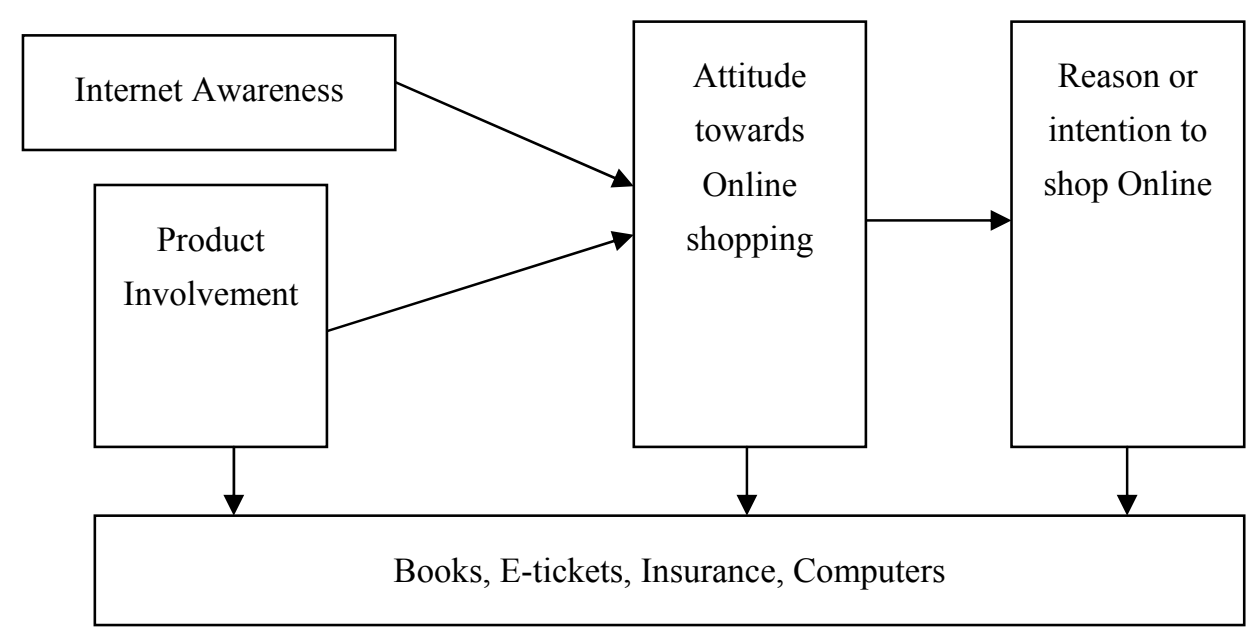

Figure 1. Product involvement research model

\subsection{Objectives of the Study}

Considering recent trends and the growth of ecommerce market in India four familiar products that fit into the product classification table of Peterson et al. (1997) were considered.

The key objectives of the study:

- To investigate the socio-demographic profile and personal internet awareness of consumers

- To examine the product involvement and consumer attitude towards online shopping for each product

- To investigate the intention to shop online for each product

In this scenario, the following hypotheses have been framed:

H1a: Product involvement will differ for each product type.

$\mathrm{H}_{1} \mathrm{~b}$ : Attitude towards online shopping will differ for each product type.

$\mathrm{H}_{1} \mathrm{c}$ : Intention to shop online will differ for each product type.

$\mathrm{H}_{1} \mathrm{~d}$ : Relationships between consumer attitude towards online shopping and product involvement will differ by product type.

$\mathrm{H}_{1} \mathrm{e}$ : Relationships between consumer attitude towards online shopping and intention to shop differ by product type.

\section{Methodology}

In due consideration of the above mentioned questions, the following methodology has been adopted for conducting the present study. The study is predominantly empirical in nature as it explores relationships among variables. Primary data was collected from Nov 2012 to Mar 2013. The current study includes sample respondents selected from among the internet users in Coimbatore city.

\subsection{Sampling Procedures}

Coimbatore city in Tamilnadu is a hub of Industries and reputed Educational Institutions. It is also an emerging IT and IT enabled services sector in India, with the IT SEZ (Special Economic Zone) located in the heart of the city. Hence Coimbatore city has been purposively chosen for the study. Creating a survey for internet shoppers presents a unique problem of identifying the respondents. Since there is no central repository of all internet shopping site visitors and online shoppers easily available, getting the sample frame is not feasible practically.

Therefore the researchers had to go for non- random sampling. The online buyer still represented only a small number of online users and given that today's college students, and professionals represent a significant part of the online buying consumers, a purposive sample of students, professionals and respondents familiar with online 
shopping interactions served as the sample respondents. A total of 125 respondents surveyed for this study.

\subsection{Survey Instrument}

The instrument was created using a five point Likert scale (strongly disagree $=1$, disagree $=2$, neither agree nor disagree $=3$, agree $=4$, strongly agree $=5$ ).

The questionnaire was first pre-tested among a convenience sample of colleagues and friends drawn from the general public. The 30 respondents in this test sample were asked to provide comments on the relevance and wording of the questionnaire items, length of the survey, and time taken to complete it. Based on the feedback received, the questionnaire layout was modified, and the questions were reworded to improve clarity.

\subsection{Products Employed}

The study has employed the product classification model proposed by Peterson et al. (1997). For the purpose of study, four products have been considered to evaluate consumer's attitude towards online shopping. Books were considered for tangible, low cost, frequently purchased products. E-tickets were considered for intangible low cost, frequently purchased products. Computers were considered for tangible, high cost, rarely purchased products and Insurance were considered for intangible high cost, rarely purchased products.

As Indian ecommerce market is still in growing phase, the degree of differentiation of products proposed by Peterson et al. (1997) was not taken into account. The products employed were carefully chosen to reflect online shopping market. The recent report published by Nielson (2010), stated that the top five products or services the global consumers expected to purchase online were Books, Clothing or accessories or shoes, airline tickets, electronic equipment, tours or hotel reservations.

\subsection{Scales Used}

The questionnaire included sections on personal information, awareness, product involvement, attitude towards shopping and perceived benefit. These items were selected from previous related research and subsequently modified for this study.

Table 2. Scales used

\begin{tabular}{lll}
\hline Item & Source \\
\hline Personal internet awareness & (adapted from Davis, Agarwal and \\
& $\begin{array}{l}\text { Prasad 1998) } \\
\text { (adapted from Lian and Lin) }\end{array}$ \\
$\begin{array}{l}\text { Product involvement } \\
\text { Attitude towards Online shopping }\end{array}$ & (adapted from Lian and Lin) \\
$\begin{array}{l}\text { Perceived benefit or intention to } \\
\text { shop online }\end{array}$ & (adapted from Hsiu-Fen Lin) \\
Demographic Profile & Developed for this study \\
\hline
\end{tabular}

\subsection{Test of Reliability}

The questions pertain to (a) awareness about internet usage (b) factors favouring different product types and (c) perceived benefits and attitude towards online shopping. Reliability analysis has been conducted by collecting data from 30 sample respondents during pilot study.

The reliability statistics of Cronbach's alpha were calculated and the results are detailed in table below.

Table 3. Cronbach's alpha

\begin{tabular}{ll}
\hline Cronbach's Alpha & $\begin{array}{l}\text { Cronbach's Alpha Based on Standardized } \\
\text { Items }\end{array}$ \\
\hline .891 & .898 \\
\hline
\end{tabular}

Since the coefficients are above 0.70 , the scales are considered to be fairly reliable.

\section{Research Findings}

The demographic variables age, gender, education, occupation, marital status, living in Coimbatore and average purchase are listed in Table 4. 


\subsection{Demographic Characteristics}

The findings indicated that the majority of respondents were females (72\%), married (77\%), between the age of 35 to 44 years old $(60 \%)$, post graduate or more $(50 \%)$, and occupation of professional and business $(32 \%$ and $35 \%$ respectively). Most of the respondents in the income group of Rupees 25001 to $55000(45 \%)$ and an average purchase of 1-5 times (56\%).

Table 4. Demographic characteristics

\begin{tabular}{lll}
\hline Variable & Description & Percent \\
\hline Age & $18-24$ & 17.6 \\
& $25-34$ & 9.6 \\
& $35-44$ & 60.8 \\
& $45-44$ & 2.4 \\
& $55-64$ & 4.8 \\
Gender & $65-74$ & 4.8 \\
Education & Male & 27.2 \\
& Female & 72.8 \\
Occupation & High School & 4.8 \\
& Graduate & 44.8 \\
& Post Graduate or more & 50.4 \\
Marital Status & House wife & 23.2 \\
Living in Coimbatore & Professional & 32.0 \\
& Business & 35.2 \\
& Student & 9.6 \\
Single & 22.4 \\
& Married & 77.6 \\
lncome Group & less than 1 year & 2.4 \\
& $1-3$ years & 35.2 \\
Average Purchase & 3-5 years & 18.4 \\
& more than 5 years & 44.0 \\
& less than 25000 & 42.4 \\
& 25001 to 55000 & 45.6 \\
& 55001 to 100000 & 4.8 \\
& 100001 to 200000 & 7.2 \\
& $1-5$ & 56.8 \\
& 6-10 & 18.4 \\
& 11 and above & 20.0 \\
& Never & 4.8 \\
\hline & &
\end{tabular}

\subsection{Personal Internet Awareness}

The results of personal internet awareness revealed a mean score of 4.3 for using the Internet to do shopping. The interaction with World Wide Web is clear and understandable with a mean score of 4.3 (Strongly Agree).

Table 5. Internet awareness

\begin{tabular}{ll}
\hline Variable & Mean \\
\hline Using the Internet makes it easier to do shopping & 4.3 \\
My interaction with World Wide Web is clear and & 4.2 \\
understandable & \\
Using Internet fits well within my lifestyle. & 3.3 \\
$\begin{array}{l}\text { I could easily use the Web to find information on } \\
\text { a product/service. }\end{array}$ & 4.5 \\
$\begin{array}{l}\text { I feel comfortable searching with World Wide } \\
\text { Web on my own. }\end{array}$ & 4.2 \\
\hline
\end{tabular}




\subsection{Product Involvement-Needed Products}

The findings revealed that E-tickets has been marked as a needed product or service with a highest mean score of 4.2, followed by Books with a mean score of 3.8.

Table 6. Product involvement-needed

\begin{tabular}{ll}
\hline Products are Needed & Mean \\
\hline Books & 3.8 \\
E-tickets & 4.2 \\
Insurance & 2.6 \\
Computers & 2.8 \\
\hline
\end{tabular}

\subsection{Product Involvement-Interesting}

The findings revealed that Books are interesting to shop online (4.2), followed by Computers (4.1), E-tickets (3.6) and Insurance (2.7).

Table 7. Product involvement-interesting

\begin{tabular}{ll}
\hline Products are Interesting & Mean \\
\hline Books & 4.2 \\
E-tickets & 3.6 \\
Insurance & 2.7 \\
Computers & 4.1 \\
\hline
\end{tabular}

\subsection{Factor Analysis of Product Involvement}

Factor analysis report indicates eigenvalue greater than one for Books and E-tickets, where the respondents indicated that the products are important. The value is greater than one for the statement 'For me the products are needed'. This factor explained $52.42 \%$ variance for Books (eigenvalue 2.62).

Table 8. Factor analysis

\begin{tabular}{lllll}
\hline Statements & Item & Communalities & Eigenvalue & Variance \\
\hline For me the products are Needed & Books & .808 & 2.62 & $52.42 \%$ \\
& E-tickets & .650 & 1.810 & $36.19 \%$ \\
& Insurance & .738 & 3.741 & $74.82 \%$ \\
& Computers & .912 & 4.00 & $80.07 \%$ \\
For me the products are important & Books & .692 & 1.033 & $20.66 \%$ \\
& E-tickets & .705 & 1.176 & $23.51 \%$ \\
& Insurance & .765 & & \\
& Computers & .864 & & \\
\hline
\end{tabular}

\subsection{Attitude towards Online Shopping}

The findings revealed that respondents like buying E-tickets (4.6) and Books (3.7) than Computers (2.8) and Insurance (2.2). Also, the respondents intend to finish the buying process totally online for E-tickets (4.4) and Books (3.6). 
Table 9. Attitude towards online shopping

\begin{tabular}{lll}
\hline Variable & Description & Mean \\
\hline I like buying the following products online. & Books & 3.7 \\
& E-tickets & 4.6 \\
& Insurance & 2.2 \\
& Computers & 2.8 \\
I intend finishing the buying processes totally online & Books & 3.6 \\
& E-tickets & 4.4 \\
& Insurance & 2.3 \\
& Computers & 2.5 \\
Buying the following products online is convenient & Books & 4.5 \\
& E-tickets & 4.6 \\
& Insurance & 3.7 \\
& Computers & 3.4 \\
\hline
\end{tabular}

\subsection{Reason to Shop Online}

The findings revealed that respondents find cheaper products online for E-tickets (3.1) and Insurance (3.2). The respondents save time by buying online for E-tickets (4.8), Books (4.6), Insurance (4.0) and Computers (4.3). It has been stated that it is easier to compare prices for Computers (4.5) and E-tickets (4.3).

There is more choice available online for Books (4.5) and E-tickets (4.0). The respondents were able to find product reviews of other customers for Books and Computers (4.4).

Table 10. Perceived benefits of online shopping

\begin{tabular}{lll}
\hline Statements & Description & Mean \\
\hline I find cheaper products Online & Books & 3.7 \\
& E-tickets & 3.1 \\
& Insurance & 3.2 \\
& Computers & 3.4 \\
I save time by buying Online & Books & 4.6 \\
& E-tickets & 4.8 \\
& Insurance & 4.0 \\
& Computers & 4.3 \\
It is easier to compare prices & Books & 4.2 \\
& E-tickets & 4.3 \\
& Insurance & 4.0 \\
There is more choice Online & Computers & 4.5 \\
& Books & 4.5 \\
& E-tickets & 4.0 \\
& Insurance & 3.9 \\
Products are delivered to a convenient place & Computers & 4.1 \\
& Books & 4.4 \\
& E-tickets & 4.3 \\
& Insurance & 3.9 \\
I can find product reviews of other customers & Computers & 4.2 \\
& Books & 4.4 \\
& E-tickets & 2.0 \\
& Insurance & 3.7 \\
& Computers & 4.4 \\
\hline
\end{tabular}

\subsection{Product Wise-Mean Ratings}

The mean score for each product for product involvement, attitude and intention to shop online is given in Table 11. The hypotheses H1a, H1b and H1c are supported for difference in the scores for each of the product. 
Table 11. Product wise - mean ratings

\begin{tabular}{llll}
\hline & $\begin{array}{l}\text { Product } \\
\text { Involvement }\end{array}$ & Attitude & $\begin{array}{l}\text { Intention to } \\
\text { shop online }\end{array}$ \\
\hline Books & 4.1 & 3.9 & 3.9 \\
E-tickets & 3.8 & 4.5 & 3.7 \\
Insurance & 3.0 & 2.6 & 3.4 \\
Computers & 3.6 & 2.9 & 3.8 \\
\hline
\end{tabular}

\subsection{Correlation Analysis}

A Pearson product-moment correlation coefficient was computed to assess the relationship between product involvement and attitude towards online shopping. There was a positive correlation between the two variables for Books, E-tickets and Computers. The hypotheses H1d and H1e are supported as the relationship between the variables differ for each product type. From Table 12, it can be concluded that consumer's attitude towards online shopping is influenced by product involvement and intention to shop online.

Table 12. Correlation analysis

\begin{tabular}{lllll}
\hline Variable & Description & $\begin{array}{l}\text { Product } \\
\text { Involvement }\end{array}$ & $\begin{array}{l}\text { Intention to } \\
\text { shop Online }\end{array}$ & $\begin{array}{l}\text { Internet } \\
\text { Awareness }\end{array}$ \\
\hline Attitude & Books & $.752^{* *}$ & $.737^{* *}$ & $.522^{* *}$ \\
& E-tickets & $.202^{*}$ & $-.186^{*}$ & $.361^{* *}$ \\
& Insurance & $-.204^{*}$ & $-.261^{* *}$ & $.388^{* *}$ \\
Computers & $.336^{* *}$ & $-.272^{* *}$ & $.804^{* *}$ \\
\hline **. Correlation is significant at the 0.01 level (2-tailed) & & \\
*. Correlation is significant at the 0.05 level (2-tailed) & & &
\end{tabular}

The correlation coefficient was computed to assess the relationship between awareness and attitude towards online shopping. There was a positive relationship between Internet Awareness and attitude towards online shopping for Computers $\left(.804^{* *}\right)$. There is no significant positive relationship between product involvement and attitude towards online shopping for Insurance.

\section{Conclusion}

The study examined how the factors of user acceptance of online shopping differ according to product or service type. Based on the findings of the study, it can be concluded that products or service type influence the relationship between factors and consumer's attitude towards online shopping. Consistent with previous research, this study found that product involvement, attitude and perceived benefit in online shopping varied with different product types.

The key findings of the study were:

The majority of respondents were in the age group of 35 to 44 years old $(60 \%)$ with an average purchase of 1-5 times $(56 \%)$. It has been indicated that the respondents could easily use the web to find information on a product or service (highest mean score of 4.5).

Books and E-tickets had high product involvement among the four products researched. Since Books are low cost, frequently purchased product, consumer's have positive attitude towards online purchasing of Books.

Girard (2003) indicated that convenience orientation was a stronger predictor for preference to shop on the Internet. In consistent with the previous research, the respondents have exhibited positive attitude towards online buying of Books (4.5) and E-tickets (4.6) as it is convenient to shop online. Also, it is indicated that the consumer's intend to finish the buying process totally online for E-tickets and Books (4.4 and 3.6).

The reason to shop online has significantly varied between different products examined in the study. The respondents save time by online buying of E-tickets (4.8) and Books (4.6). Though the reason to buy Insurance online was to save time (4.0), the intention to finish buying Insurance totally online was less (2.3). It has been stated that it was easier to compare prices for Computers and E-tickets. Since Computers are high cost, tangible products with more features to compare, the intention to finish buying online was less for computers. It has been stated that there was more choice available online for Books (4.5) and E-tickets (4.0). The respondents were able 
to find product reviews of other customers for Books and Computers (4.4).

Prior studies indicated that product involvement and attitude towards online shopping was different for each product type (Ellisavet 2011). It was found that intangible products like subscription and E-tickets had greater product involvement, followed by E-tickets (Ellisavet et.al 2011). In the present study the respondents have indicated that it is more convenient to buy E-tickets and Books online. There is a positive relationship between product involvement and attitude towards online shopping for Books, E-tickets and Computers.

The findings of this study are limited to only one product for each product category considered for the research. Future research can include more products to study the influence of different factors on consumer's attitude towards online shopping. Furthermore, future research can identify the differences between online shoppers and non-shoppers in different trait levels.

\section{Acknowledgements}

This paper is part of ongoing Ph.D research.

\section{References}

Agarwal, R., \& Prasad, J. (1998). A conceptual and operational definition of personal innovativeness in the domain of information technology. Information Systems Research, 9(2), 204-215. http://dx.doi.org/10.1287/isre.9.2.204

Batra, R., \& Ahtola, O. (1990). Measuring the Hedonic and Utilitarian Sources of Consumer Attitudes. Marketing Letters, 2(2), 159-170. http://dx.doi.org/10.1007/BF00436035

Carol, K.-S., \& Jay, D. L., (2002). E-shopping in a multiple channel environment. Journal of consumer marketing, 19(4), 333-350. http://dx.doi.org/10.1108/07363760210433645

Doolin, B., Dillon, S., Thompson, F., \& James, L. C. (2005). Perceived risk, the Internet shopping experience and Online purchasing behavior: A New Zealand Perspective. Journal of Global Information Management, 13(2), 66-88. http://dx.doi.org/10.4018/jgim.2005040104

Forsythe, S., Liu, C., Shannon, D., \& Liu, C. G. (2006). Development of a scale to measure the perceived benefits and risks of online shopping. Journal of interactive marketing, 20(2), 55-75. http://dx.doi.org/10.1002/dir.20061

Girard, T., Korgaonkar, P., \& Silverblatt, R. (2003). Relationship of Type of Product, Shopping Orientations, and Demographics with Preference for Shopping on the Internet. Journal of Business and Psychology, 18(1), 101-120. http://dx.doi.org/10.1023/A:1025087021768

Jarvenpaa, S. L., Tractinsky, N., \& Vitale, M. (2000). Consumer Trust in an Internet Store. Information Technology and Management, 1(1), 45-71. http://dx.doi.org/10.1023/A:1019104520776

Keisidou, E., Sarigiannidi, L., \& Maditinos, D. (2011). Consumer characteristics and their effect on accepting online shopping, in the context of different product types. Int. Journal of Business Science and Applied Management, 6(2), 31-51.

Kim, J. (2004). Understanding Consumers Online Shopping and Purchasing Behavior. Ph.D Thesis, Oklahoma State University.

Lastovicka, J. L. (1979). Questioning the Concept of Involvement Defined Product Classes. In L. William \& Ann Abor Wilkie (Eds.), Advances in Consumer Research (pp. 174-179). MI: Association for Consumer Research.

Lian, J.-W., \& Lin, T.-M. (2008). Effects of consumer characteristics on their acceptance of online shopping: Comparisons among different product types. Computers in Human Behavior, 24(1), 48-65. http://dx.doi.org/10.1016/j.chb.2007.01.002

Liang, T. P., \& Huang, J. S. (1998). An empirical study on consumer acceptance on products in electronic markets: A transaction cost model. Decision Support Systems, 24, 29-43. http://dx.doi.org/10.1016/S0167-9236(98)00061-X

Lin, H.-F. (2007) Predicting consumer intentions to shop online: An empirical test of competing theories. $\begin{array}{llll}\text { Electronic Commerce Research and } & \text { Applications, }\end{array}$ http://dx.doi.org/10.1016/j.elerap.2007.02.002

Nielsen. (2010). Global Trends in Online Shopping. A Nielsen Global Consumer Report.

Park, N., Lee, K. M., \& Cheong, P. H. (2007). University instructors' acceptance of electronic courseware: An 
application of the technology acceptance model. Journal of Computer-Mediated Communication, 13(1). http://dx.doi.org/10.1111/j.1083-6101.2007.00391.x

Peterson, R. A., Balasubramanian, S., \& Bronnenberg, B. J. (1997). Exploring the implications of the Internet for consumer marketing. Journal of Academy of Marketing Science, 25(4), 329-346. http://dx.doi.org/10.1177/0092070397254005

Phau, I., \& Poon, S. M. (2000). Factors influencing the types of products and services purchased over the Internet. Internet Research, 10(2), 102-113. http://dx.doi.org/10.1108/10662240010322894

Ramayah, T., \& Ignatius, J. (2010). Intention to Shop Online: The Mediating Role of Perceived Ease of Use. Middle-East Journal of Scientific Research, 5(3), 152-156.

Sebastianelli, R., Tamimi, N., \& Rajan, M. (2007). How Shopping Frequency and Product Type Affect Consumers' Perceptions of E-Tailing Quality. Journal of Business \& Economics Research, 5(1).

Swaminathan, V., Lepkowska-White, E., \& Rao, B. P. (1999). Browsers of buyers in cyberspace? An investigation of factors influencing electronic exchange. Journal of Computer-Mediated Communication, $5(2)$.

Swati Prasad for Inside India. (January 29, 2013). Online shopping catching fancy of Indian consumers. Journal of Academy of Marketing Science, 25(4), 329-346.

Team, Y. S. (2013). Google India Study reports numbers about online shopping in India; 'Electronics' Top Search but 'Apparels' bost bought. Retrieved http://yourstory.in/2013/01/google-india-study-about-online-shopping/

Zaichkowsky, J. L. (1985). Measuring the involvement construct. Journal of Consumer Research, 12(3), 341-352. http://dx.doi.org/10.1086/208520

Zuroni, M. J., \& Goh, H. L. (2012). Factors influencing consumers' attitude towards e-commerce purchases through online shopping. International Journal of Humanities and Social Science, 2(4).

\section{Copyrights}

Copyright for this article is retained by the author(s), with first publication rights granted to the journal.

This is an open-access article distributed under the terms and conditions of the Creative Commons Attribution license (http://creativecommons.org/licenses/by/3.0/). 